\title{
Linking earned income, psychological capital and social grant dependency: empirical evidence from rural KwaZulu-Natal (South Africa) and implications for policy
}

\author{
U. Chipfupa* and E. Wale
}

\section{${ }^{*}$ Correspondence:}

uchipfupa@gmail.com

School of Agricultural, Earth and Environmental Sciences,

University of KwaZulu-Natal, Private Bag X01, Scottsville, Pietermaritzburg 3209, South Africa

\begin{abstract}
Understanding the motivation that smallholders have for working and earning their livelihood is critical in enhancing the effectiveness of agricultural policies. This is especially important in a country like South Africa where social grant is an important source of unearned income. The study sought to find out what affects smallholders' motivation to work by assessing the relationship between earned income, psychological capital and social grant dependency. We use data from 458 smallholders in four irrigation communities in rural KwaZulu-Natal and employ a complementary loglog fractional response model to analyse the data. The study revealed that endowment with positive psychological capital, gender, membership to an irrigation scheme and land ownership positively affect smallholders' propensity to earn their livelihoods from farm and non-farm income. Social grant support and dependency ratio negatively affect the same. The findings support the thesis that, if not properly managed, social transfers can have a negative impact on smallholders' motivation to work and earn their livelihoods, resulting in a dependency syndrome. Depending on the context, spatial differences can either positively or negatively affect farmers' motivation to work. In conclusion, limited focus on the human and social capital development and hence psychological capital affect smallholders' propensity to work. Small-scale irrigation schemes remain a viable option for increasing employment and incomes in the sector, whilst social and cultural norms continue to reduce women's ability to engage in economic activities. The paper recommends the need to recognise the critical importance of psychological capital (mindset), streamline and improve targeting of social grant support, promote smallholder irrigation and invest in the infrastructure that enhances participation of women in economic activities.
\end{abstract}

Keywords: Unearned income, Motivation to work, Psychological capital, Social grant, Rural livelihoods

\section{Introduction}

The future of agriculture in Africa is fundamentally linked to the creation of a conducive and enabling policy and regulatory environment for rural farmers to participate and compete for opportunities in the agri-food systems sector (AGRA 2017; Jayne 
et al. 2017). However, a supportive environment alone is not enough for a meaningful transformation. Smallholders also need to possess both technical and psychological abilities which enable them to derive the most from the sector (Frese and Gielnik 2014). Whilst extensive efforts have been made to improve the technical capacity of smallholder farmers in terms of knowledge, skills and experience (Twomlow et al. 2008; Nampanya et al. 2012; Shiferaw et al. 2014), not much has been done about their mindset and psychological attributes. These aspects, also known as the psychological capital (PsyCap), deal with the smallholder farmers' mindset, a critical asset of their livelihood (Sigelman and Zeng 2000; Chipfupa and Wale 2018b). They significantly influence smallholder behaviour, especially how smallholders respond to opportunities and agricultural policy incentives. There are recent studies that have shown the importance of PsyCap in determining livelihoods of smallholder irrigation farmers in South Africa (Chipfupa and Wale 2018a; Phakathi and Wale 2018). They demonstrate that poor endowment with the asset manifests in several forms such as low aspirations, external locus of control, and lack of motivation to achieve more in life and dependency syndrome. As a result, this could lead to negative and unexpected behavioural responses which affect the effectiveness of policies in enhancing the performance of the agricultural sector.

Several studies, mostly in the workplace, have demonstrated the importance of work motivation in improving employee performance (Vroom 1964; Lawler and Porter 1967; Gagné and Deci 2005). This is supported by motivational theories from psychology, which indicate that individuals are motivated to work for something that produces a desired outcome in their lives, also known as extrinsic motivation (McClelland and Winter 1969; Heckhausen and Heckhausen 1991). The same principle also applies to smallholder farmers. They exert their effort in farming to improve their livelihoods through influencing outcomes such as achievement of food self-sufficiency and income security (Danso et al. 2002; Aliber and Hart 2009). These outcomes, ceteris paribus, thus act as incentives to motivate farmers to invest both their time and money into farming. However, if smallholders can, through some other means, still achieve a minimum acceptable standard of living (acceptable to themselves) without taking any action, then their motivation to work is likely to be significantly reduced. For instance, whenever there are more opportunities for receiving unearned income, there will be less effort, investment and entrepreneurship both on and off the farm (Matshe and Young 2004). Thus, understanding the dynamics between motivation and livelihood outcomes is an essential step in creating a sustainable smallholder agricultural sector.

Studies in South Africa have shown the ratio of earned compared to unearned income amongst smallholder farming households to be ranging between 1:2 and 1:3 (Sinyolo et al. 2017; Chipfupa 2018). This income structure suggests that most smallholders' livelihood is obtained through unearned means. This has tremendous negative ramifications for the effectiveness of agricultural development policies. Matshe and Young (2004) found out that unearned income reduces the likelihood of both participation and time spent on off-farm work. A similar relationship is likely to exist even with on-farm work. Most of the unearned income that households receive in South Africa comes from the social grant support (Statistics South Africa 2019). At face value, the grant seems too little to have any significant impact on smallholders' behaviour (see Table 2). However, 
recent studies show that when aggregated per household, it constitutes a substantial share of the household income (Sinyolo et al. 2017; Chipfupa 2018).

Nevertheless, social protection policies remain an integral component of the South African economy. They offer a mechanism for protecting the most vulnerable members of the community and reducing the structural inequalities in society (Godfrey et al. 2016; Hanass-Hancock and McKenzie 2017). The latter part is critical given South Africa's history of apartheid and the need to uplift the standard of living of poor communities unable to earn their living. Chakona and Shackleton (2019) showed that, indeed, households that receive social grants were more food insecure. The remaining challenge, though, is the unintended impact of the program on the recipients' and beneficiaries' locus of control (Sinyolo et al. 2017). This is evident in terms of the conflict between social protection and development policies, which are meant to complement one another. Scanning through the literature produces conflicting evidence of the impact of social transfers on employment. Some studies show that social transfers enhance smallholders' investment in agriculture (Ardington et al. 2009; Daidone et al. 2019). However, others indicate that they reduce the incentives for employment (Moffitt 2002; Bertrand et al. 2003). Hence, the need to empirically test the effect of social transfers such as social grants on smallholder household's propensity to work and earn their livelihoods.

The potential of the agricultural sector in Sub-Saharan Africa to develop rural economies and contribute more to improving the standard of living in such communities has been widely acknowledged (AGRA 2017; Jayne et al. 2017). However, the continued underperformance of the sector still raises many unanswered questions, such as, why have agricultural and rural development policies across the continent so far failed to produce the desired effect? Why did the green revolution technologies generally fail in Sub-Saharan Africa? Could this be linked to pro-poor policy inconsistencies in the region? There would not be one solution to this problem but understanding its different dimensions is critical to designing a comprehensive package of strategies for addressing the challenges. Aiming to contribute to addressing these challenges, this study focuses on one such dimension of this problem which has rarely been studied. Most studies focus on the more structural elements of the problem such as agricultural technology adoption, conducive policy environment, and market distortions, amongst others, and less on the human mindset and social aspects (Bembridge 2000; Fanadzo 2012). Hence, there is the need to give more attention to the human and social assets of smallholders as drivers of transformation in the sector.

This study seeks to understand what affects smallholders' motivation to work and earn their livelihoods. In so doing, it assesses the relationship between the proportion of earned income in smallholder rural households, psychological capital and social grant dependency. Using data from four irrigation farming communities in KwaZuluNatal, South Africa, the study first establishes the proportion of earned and unearned income amongst different smallholder farmer typologies. The typologies are constructed based on the level of PsyCap endowment amongst the farmers. An empirical model is then employed to explain the determinants of the level of earned income available in a rural household. Given the results, a question is asked whether there is motivation for rural households to put more effort into securing their livelihoods, i.e., in committing both resources and time to farming. In the end, the paper discusses the conditions 


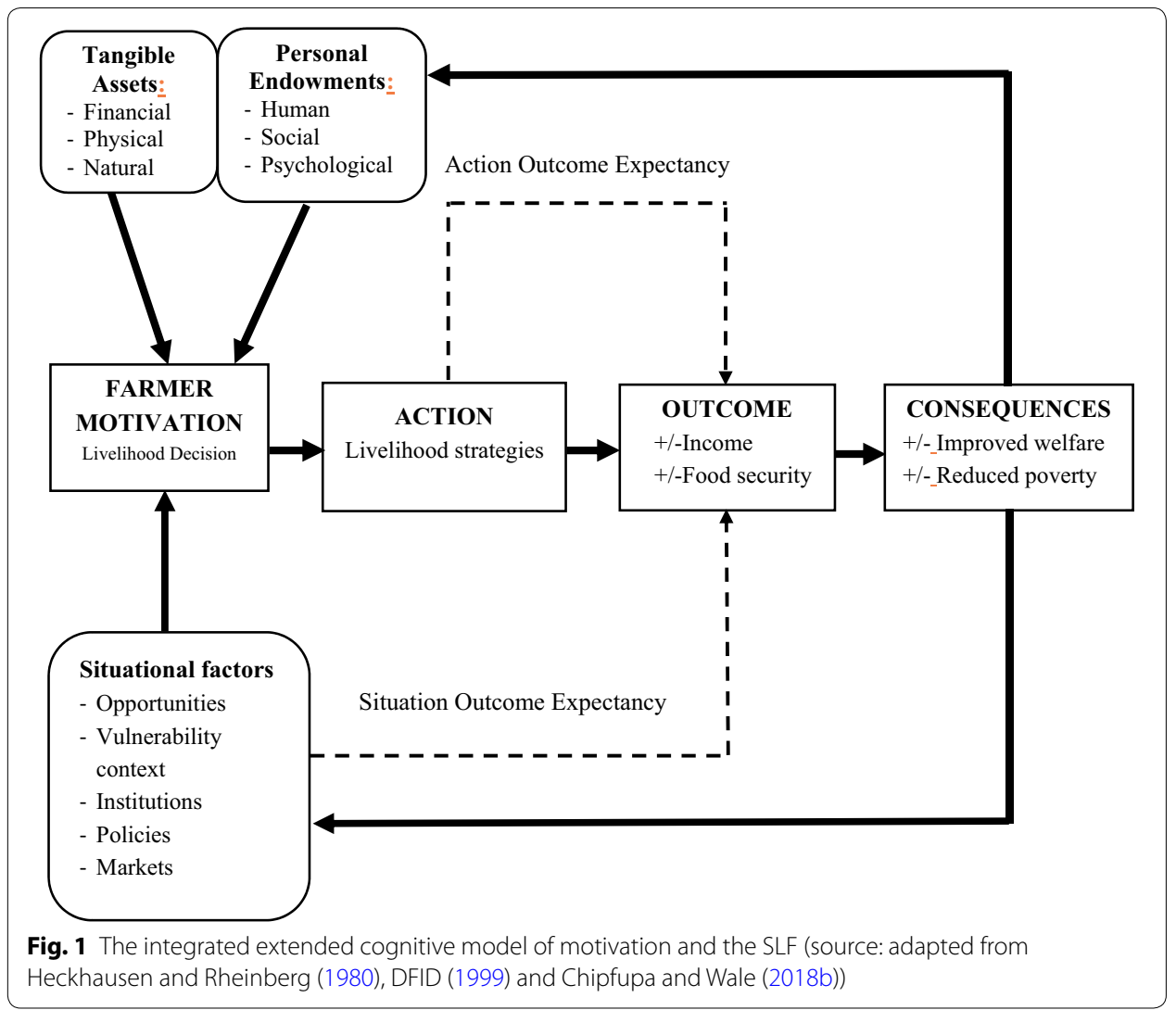

under which rural development policies would improve the livelihood outcomes of rural communities.

\section{Conceptual framework}

The study is based on the integration of three concepts, i.e., the Extended Cognitive Model of Motivation (Heckhausen and Rheinberg 1980), the Sustainable Livelihoods Framework (SLF) (DFID 1999; De Satge 2002) and positive psychology (Luthans et al. 2004). Figure 1 presents an illustration of this relationship. Motivation is defined as the "activating orientation of current life pursuits towards a positively evaluated goal state" (Rheinberg 2004). It involves people committing resources to achieve the desired outcome. Smallholder motivation to invest and exert effort in farming is mainly associated with the need to maintain food self-sufficiency and earn income. Ultimately, this contributes to a sustainable livelihood, i.e., improvement in welfare and reduction in poverty. Their action is in the form of different livelihood strategies such as farming (crop and livestock), off-farm employment, arts and crafts, and small business operation, amongst others, taken to achieve the desired outcome (De Satge 2002).

Motivation is affected by both personal and situational factors (Rheinberg 1989). Personal factors are livelihood assets and endowments that a household possesses. According to the SLF, these include the tangible assets (financial, physical and natural assets) and personal endowments (human, social and psychological assets) (De Satge 2002; Chipfupa and Wale 2018b). PsyCap is included amongst these assets to represent the 
farmers' level of confidence, optimism, resilience and hope. The situational factors include the institutions, processes, policies and the vulnerability context within which the farmers operate (De Satge 2002). They present opportunities and incentives that motivate smallholders to act.

According to the Extended Cognitive Model of Motivation, people's motivation, i.e., their propensity to act, significantly depends on their expectancies and the available incentives (Heckhausen and Rheinberg 1980). The situation-outcome expectancy (S_O Expectancy) shows the subjective beliefs of individuals regarding the possibility of them obtaining a given outcome without putting any effort (Heckhausen and Heckhausen 1991). If smallholders believe that a minimum acceptable living can be achieved without their effort, then their incentive to act is reduced. The reverse is true for the actionoutcome expectancy (A_O Expectancy). If smallholder farmers believe that their actions will result in a particular desirable outcome, their incentive to act is increased. This drives them to put more effort in activities that will earn them an income and improve their welfare. Through the feedback loop, these outcomes and consequences ${ }^{1}$ will, in turn, affect the personal and situational factors of each smallholder. Understanding this interaction between motivation, resources and action is important to finding solutions for enhancing the effectiveness of agricultural policies.

\section{Data and methods}

\subsection{Study area and data collection}

The study covered four irrigation schemes (Makhathini, Ndumo-B, Bululwane and Tugela Ferry) in UMkhanyakude, Zululand and UMzinyathi districts, KwaZulu-Natal, South Africa. KwaZulu-Natal has the highest number of agricultural households in the country (Statistics South Africa 2016). Compared to other provinces, it is amongst the poorest province. Its poverty headcount $(68.1 \%)$ is the third highest in the country (Statistics South Africa 2017). The selected irrigation schemes are part of the government's irrigation revitalisation programme meant to transform smallholder agriculture in South Africa. All schemes are operating just at more than half their capacity and there is potential for expansion and scaling up. Three of the schemes are managed and operated by the farmers through their cooperatives whilst one (Makhathini) is managed by a third-party organisation on behalf of the government.

The study targeted 458 smallholder irrigation farmers (in and out of the schemes). Data collection was conducted in 2016 through a questionnaire survey. The questionnaire collected information of household sources of income, agricultural production, marketing, asset ownership, land ownership and social networks, amongst other socioeconomic indicators. The farmers who participated were first stratified by the type of irrigation before being randomly selected for the survey. They were identified through the local Department of Agriculture and Rural Development offices, which provided the list of irrigation farmers in the schemes. There was no information regarding the irrigation farmers outside of the schemes. However, these were identified through the survey.

${ }^{1}$ Consequences are higher level outcomes resulting from an action outcome. 


\subsection{Descriptive analysis, principal component analysis and clustering}

Analysis of Variance (ANOVA) was used to describe the characteristics of smallholder farming households per farmer typology and the proportion of household earned income. The farmer typologies were developed from the PsyCap indicators. The study adopted an approach similar to that implemented by Goswami et al. (2014) and Chipfupa and Wale (2018b). Principal component analysis (PCA) was first applied to the 12 indicators of PsyCap to reduce the dimensionality of the data. The resulting factors were subjected to K-Means clustering to identify the farmer typologies based on their PsyCap endowment.

\subsection{Empirical model}

A fractional response model was deemed most appropriate for the estimation of the empirical model of the study (Papke and Wooldridge 1996). The response variable, the proportion of household's earned income, is naturally a fraction bounded between 0 and 1 . The functional form of a fractional response model allows the predicted values to lie in the unit interval, which is not possible with a linear transformation such as Ordinary Least Squares. Application of the Tobit model is also problematic because of its restrictive assumptions on the dependent variable, and the fact that observations at the boundaries of a fractional variable are not due to censoring but natural consequences (Ramalho et al. 2011). Although Papke and Wooldridge (1996) indicate that the log-odds function could handle proportional data, the problem arises when most of the observations take on the values of 0 and 1 . This means some adjustments have to be made, which potentially affect the efficiency of the model (Ramalho et al. 2011).

Following, Papke and Wooldridge (1996), the conditional expectation of the proportion of earned income in a household, $E(y \mid x)$ is given by

$$
E(y \mid x)=G(x \theta),
$$

where $y$ represents the dependent variable, which is bounded between 0 and $1, x$ are the explanatory variables and $\theta$ is a vector of parameters. $G($.$) is a cumulative distri-$ bution function, which takes several forms such as the logit $-G(x \theta) \equiv e^{x \theta} /\left(1+e^{x \theta}\right)$

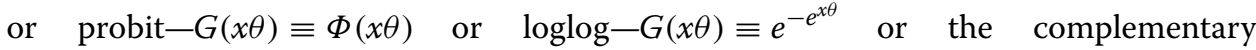
$\log \log -G(x \theta) \equiv 1-e^{-e^{x \theta}}$ functions (Ramalho et al. 2011).

Equation (1) can be estimated using a quasi-maximum likelihood method (QML) based on the following Bernoulli log-likelihood function (Papke and Wooldridge 1996):

$$
\mathrm{LL}_{i}=y_{i} \log \left[G\left(x_{i} \theta\right)\right]+\left(1-y_{i}\right) \log \left[1-G\left(x_{i} \theta\right)\right] .
$$

The QML estimator of $\theta$ is thus defined by

$$
\hat{\theta}=\arg \max \sum_{i=1}^{N} \mathrm{LL}_{i}(\theta) .
$$

The QML estimator is consistent and asymptotically normal for any distribution of $y_{i}$ conditional on $x_{i}$, as long as Eq. (1) is correctly specified (Ramalho et al. 2011). The marginal effects of all the functional forms for the distribution of $G($.) are given by 


$$
g(x \theta)=\frac{\partial G(x \theta)}{\partial x \theta} .
$$

According to Wooldridge (2010) and Ramalho et al. (2011), the estimation of Eq. (1) is most appropriate when the fractional response variable (proportion of earned income) is not defined at the boundary values. However, where a significant portion of the smallholder households earn none or all their income (for example, in this study $26.9 \%$ and $14.8 \%$ are 0 s and 1 s, respectively), the simple one-part model might not produce the best results. They recommend the estimation of a two-part model which estimates the discrete part as a binary and the continuous part as a fractional regression model.

The first part estimates a binary choice model which determines the probability that smallholder farmers earn some or all their household income.

Define

$$
y^{*}=\left\{\begin{array}{ll}
0 & \text { for } y=0 \\
1 & \text { for } y \in(0,1]
\end{array} .\right.
$$

Then,

$$
\operatorname{Pr}\left(y^{*}=1 \mid x\right)=E\left(y^{*} \mid x\right)=F\left(x \beta_{1 P}\right),
$$

where $\beta_{1 \mathrm{P}}$ is the vector of parameter estimates and $F($.$) the cumulative distribution$ function, which can also take several forms. The second part estimates the fractional response model on the non-zero or positive outcomes. The function is specified as follows:

$$
E[y \mid x, y \in(0,1)]=M\left(x \beta_{2 P}\right)
$$

Both parts of the model can be estimated with the same explanatory variables. This makes it possible to check if the same variables affect the first and second parts differently. Given Eqs. 6 and 7, the conditional mean of the two-part model is thus given by

$$
\begin{aligned}
E(y \mid x) & =E[y \mid x, y \in(0,1)] \cdot \operatorname{Pr}[y \in(0,1) \mid x] \\
& =M\left(x \beta_{2 P}\right) \cdot F\left(x \beta_{1 P}\right) .
\end{aligned}
$$

The explanatory variables used in the regression model are contained in Table 4. These included the household demographic variables (gender, education level, experience and dependency ratio), socio-economic factors (access to credit, social grant support, access to markets, and asset ownership) and social networks. To account for the heterogeneity of smallholder farmers due to their endowment with PsyCap and location, dummy variables for the farmer typologies and the study areas were included in the model. Makhathini was taken as the base category for location because it is significantly different in scale, management and performance from the other schemes. The scheme is larger in size and scale of operations, and whereas other schemes are managed by smallholder cooperatives, Makhathini is managed by a quasi-government institution on behalf of the farmers. 


\subsection{Model specification testing}

The study used three robust specification tests to assess the model specification, i.e., RESET test, goodness of functional form tests (GOFF-I and GOFF-II) (Ramalho et al. 2011) and the $P$ test (Davidson and MacKinnon 1981). The first two classes of tests are used to check the appropriateness of the functional forms of either one-part or two-part models whilst the $P$ test is used to test the specification of one model against the other (Ramalho et al. 2011). In this study, different functional forms of the one-part model were tested separately and against each other to determine the most suitable given the distribution of the response variable. A similar process was also conducted for the first and second components of the two-part model. After determining the suitable functional forms, the $P$ test was used to determine the most appropriate model between the one-part model and the two-part model (see Table 1 for results).

For the one-part model, only the cloglog model is appropriate (not rejected at $10 \%$ ). The model was also not rejected when tested against the other models. The results for the first component of the two-part model show that all models are acceptable. However, the loglog model was not appropriate when tested against the logit and the cloglog models. In the second component of the two-part model, only the cloglog model is admissible. Thus, given that the cloglog model is never rejected in both the one-part and two-part models, it was selected as the best functional form for the estimation. Indeed, this is supported by the distribution of the response variable, which is asymmetrical. The $P$ test for the one-part versus the two-part model showed that the former is a better model. Hence, the study estimates and interprets the one-part model using the cloglog distribution function.

\section{Results}

\subsection{PsyCap-based farmer typologies}

Principal component analysis followed by K-Means clustering showed that smallholder irrigation farmers could be classified into three farmer typologies based on their PsyCap. The data were appropriate for PCA. The KMO measure of sampling adequacy was 0.82 and the Bartlett's test of Sphericity was significant at 1\%. The results from PCA yielded four dimensions of PsyCap, i.e., endowment with positive PsyCap, risk-taking and limited interest in farming, long-term focused and adventurous, and self-reliant and resilient. The application of K-Means clustering to the four factors resulted in three clusters with final cluster centres shown in Fig. 2. The PCA results and the K-Means clustering ANOVA table are contained in Additional file 1.

Cluster 1 (40.2\%) represents smallholder farmers who, though having a limited interest in farming as a source of livelihood, are not afraid to take calculated risk. Cluster $2(32.5 \%)$ represents smallholders who are self-reliant and resilient. Their ability to cope with shocks such as drought is high. Cluster 3 (27.3\%) represents farmers who are endowed with positive PsyCap and are long-term thinkers. Such farmers are confident, optimistic and hopeful, and believe in their abilities. These results are similar to several studies which have shown the existence of different farmer typologies amongst smallholder farmers, an indication of their heterogeneity (Bigodeza et al. 2009; Goswami et al. 2014). 


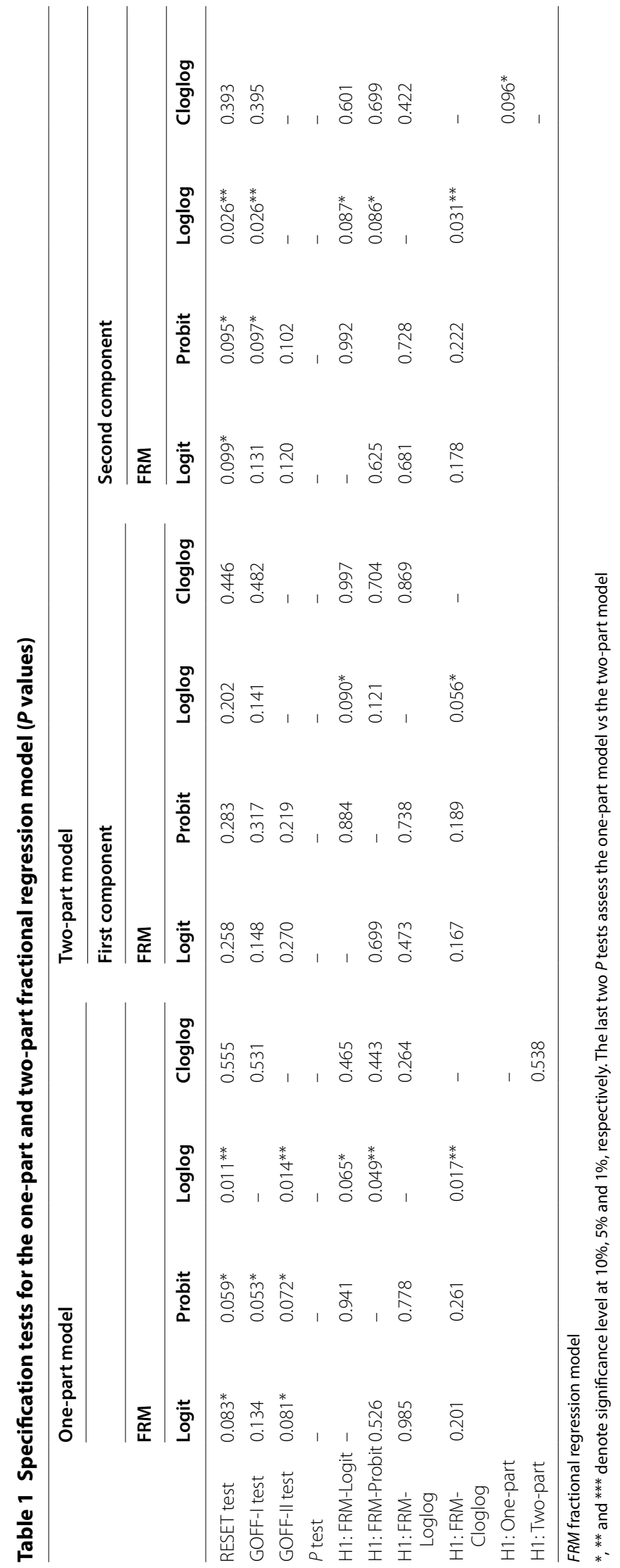




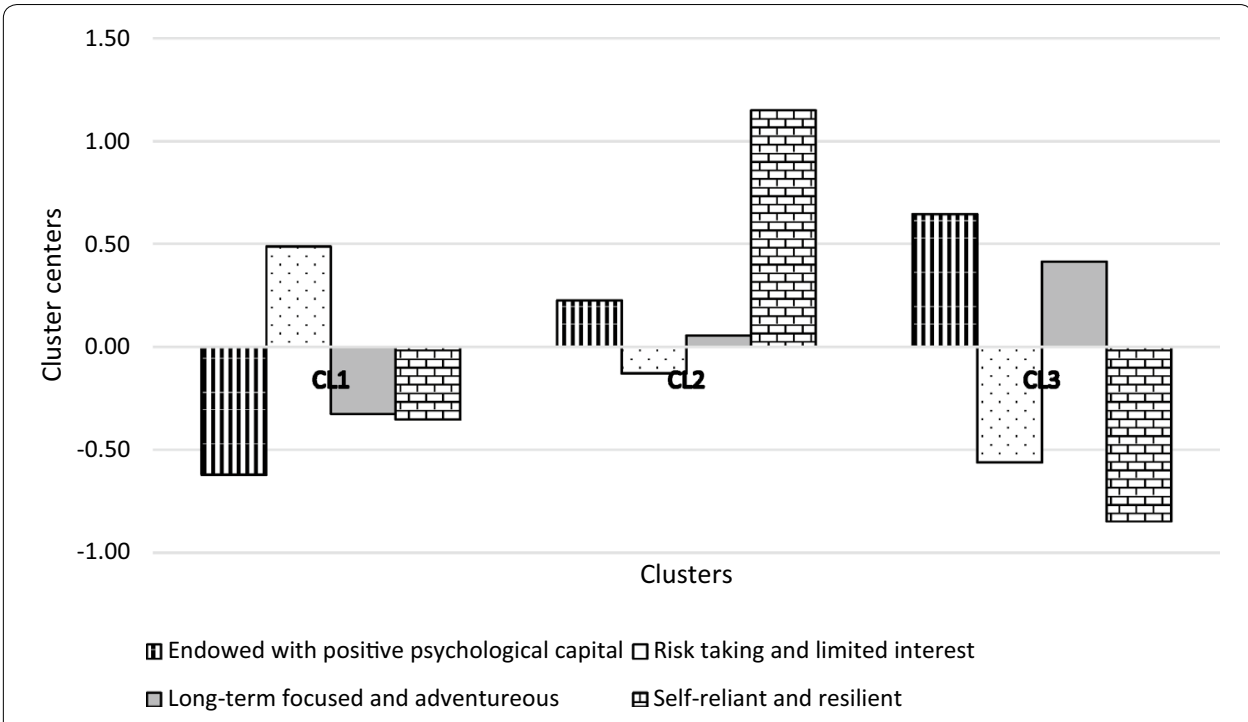

Fig. 2 Final cluster centres from K-Means clustering (source: Survey Data, April 2017)

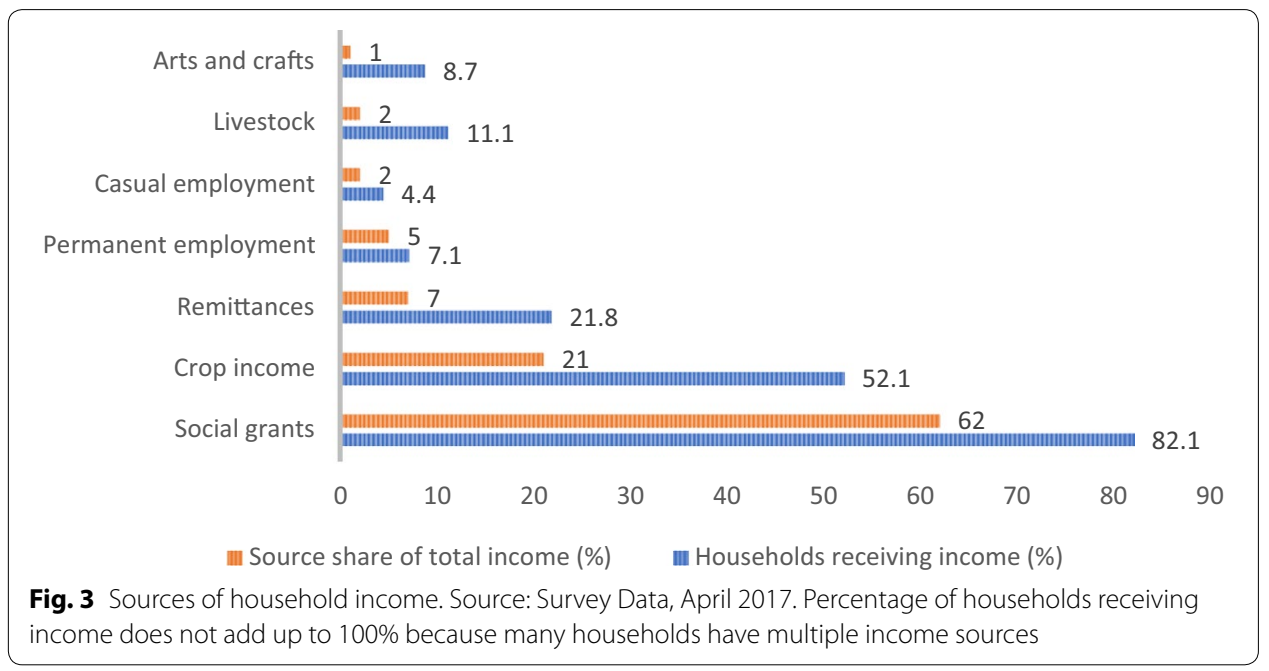

\subsection{Socio-economic characteristics}

\subsubsection{Household income dynamics}

Most of the smallholder household income is unearned, i.e., it is received from social grant support and remittances (Fig. 3). Social grants are a government programme designed to help the most vulnerable members of the society (see Table 2). The South African government considers social grants as targeted. However, social grant incomes benefit the non-targeted household members as household income is often shared amongst the members. Social grant support constitutes approximately $62 \%$ share of the total household income compared to farming which contributes 23\% (crop and livestock). About $82 \%$ of the sampled households are receiving social grant support. Together with remittances, they make just over two-thirds of the smallholder annual income. 
Table 2 Monthly values of social grant support. Source: National Treasury (2019)

\begin{tabular}{lc}
\hline Type of grant & Value (ZAR) \\
\hline Old age & 1780 \\
Old age, over 75 years & 1800 \\
War veterans & 1800 \\
Disability & 1780 \\
Foster care & 1000 \\
Care dependency & 1780 \\
Child support & 425 \\
Grant in aid & 410 \\
\hline
\end{tabular}

ZAR South African Rands

Table 3 Mean household income estimates for different farmer typologies. Source: Survey Data, April 2017

\begin{tabular}{|c|c|c|c|c|c|c|}
\hline \multirow[t]{2}{*}{ Source of income } & \multicolumn{3}{|l|}{ Farmer typologies } & \multirow[t]{2}{*}{ All } & \multirow[t]{2}{*}{$P$ value } & \multirow{2}{*}{$\begin{array}{l}\text { \% } \\
\text { of total } \\
\text { income }\end{array}$} \\
\hline & $\begin{array}{l}\text { Risk-taking } \\
\text { and limited } \\
\text { interest in farming }\end{array}$ & $\begin{array}{l}\text { Self-reliant } \\
\text { and resilient }\end{array}$ & $\begin{array}{l}\text { PsyCap } \\
\text { and future } \\
\text { focused }\end{array}$ & & & \\
\hline $\begin{array}{l}\text { Earned income } \\
\text { (ZAR) }\end{array}$ & $\begin{array}{l}6648 \\
(17,333)\end{array}$ & $\begin{array}{l}13,249 \\
(51,589)\end{array}$ & $\begin{array}{l}8669 \\
(19,271)\end{array}$ & $\begin{array}{l}9347 \\
(33,031)\end{array}$ & 0.187 & 31 \\
\hline $\begin{array}{l}\text { Unearned income } \\
\quad(Z A R)\end{array}$ & $\begin{array}{l}19,395 \\
(17,134)\end{array}$ & $\begin{array}{l}19,810 \\
(17,391)\end{array}$ & $\begin{array}{l}25,037 \\
(30,227)\end{array}$ & $21,070(21,665)$ & 0.055 & 69 \\
\hline Total income (ZAR) & $\begin{array}{l}26,043 \\
(23,668)\end{array}$ & $\begin{array}{l}33,058 \\
(54,304)\end{array}$ & $\begin{array}{l}33,707 \\
(36,147)\end{array}$ & $30,417(39,329)$ & 0.148 & \\
\hline
\end{tabular}

In brackets are standard deviations

The mean annual income estimated for the sampled households is ZAR30,417, of which only ZAR9347 is earned from various household on-farm and off-farm incomegenerating activities (Table 3). Smallholder households classified as 'self-reliant and resilient' earn a higher proportion of their income compared to the other farmer typologies. Those classified as being 'endowed with positive PsyCap' have a higher average unearned income per year. The amount of unearned income per household depends on the type of grant support received and the number of household members receiving the support (see further discussion referring to Table 4). These results are in line with the KwaZuluNatal provincial statistics on social grant support. Statistics South Africa (2018) reports that the province had $36.4 \%$ of its population and $49.5 \%$ households receiving social grants compared to the national averages of $30.8 \%$ and $43.8 \%$, respectively. The report further shows that unearned income (social grants and remittances) is the main source of livelihoods for $34.5 \%$ households in the province. This shows the level of dependency on unearned income amongst rural households in the province.

\subsubsection{Household characterisation by level of earned income}

Table 4 shows that the level of earned income in a household has a relationship with the gender of the household head, the dependency ratio, social grant support, land ownership, PsyCap and location. Male farmers have higher levels of earned income whilst households with more dependents rely more on unearned income compared to their counterparts. Though the relationship between the proportion of earned income and 
Table 4 Characteristics of sampled households by proportion of earned income. Source: Survey Data (April 2017)

\begin{tabular}{|c|c|c|c|c|c|c|}
\hline & $\begin{array}{l}Y_{\mathrm{E}}=0 \% \\
(n=113)\end{array}$ & $\begin{array}{l}0 \%<Y_{E}<50 \% \\
(n=196)\end{array}$ & $\begin{array}{l}50 \%=<Y_{\mathrm{E}}<100 \% \\
(n=71)\end{array}$ & $\begin{array}{l}Y_{\mathrm{E}}=100 \% \\
(n=68)\end{array}$ & Total & $P$ value \\
\hline $\begin{array}{l}\text { Gender of } \\
\text { household } \\
\text { head (GEN- } \\
\text { DER) }\end{array}$ & $\begin{array}{l}0.28 \\
(0.45)\end{array}$ & $\begin{array}{l}0.24 \\
(0.43)\end{array}$ & $\begin{array}{l}0.46 \\
(0.50)\end{array}$ & $\begin{array}{l}0.47 \\
(0.50)\end{array}$ & $\begin{array}{l}0.32 \\
(0.47)\end{array}$ & 0.000 \\
\hline $\begin{array}{l}\text { Level of educa- } \\
\text { tion (EDUCAT) } \\
\text { (years) }\end{array}$ & $\begin{array}{l}4.14 \\
(4.12)\end{array}$ & $\begin{array}{l}4.59 \\
(4.59)\end{array}$ & $\begin{array}{l}3.97 \\
(4.25)\end{array}$ & $\begin{array}{l}4.47 \\
(5.04)\end{array}$ & $\begin{array}{l}4.36 \\
(4.49)\end{array}$ & 0.716 \\
\hline $\begin{array}{l}\text { Experience } \\
\text { in farming } \\
\text { (EXPERIE) } \\
\text { (years) }\end{array}$ & $\begin{array}{l}16.26 \\
(13.46)\end{array}$ & $\begin{array}{l}15.40 \\
(12.42)\end{array}$ & $\begin{array}{l}16.94 \\
(12.63)\end{array}$ & $14.01(10.28)$ & $\begin{array}{l}15.65 \\
(12.42)\end{array}$ & 0.516 \\
\hline $\begin{array}{l}\text { Dependency } \\
\text { ratio (DEP_RT) }\end{array}$ & $\begin{array}{l}0.99 \\
(1.12)\end{array}$ & $\begin{array}{l}1.00 \\
(1.08)\end{array}$ & $\begin{array}{l}0.67 \\
(0.63)\end{array}$ & $\begin{array}{l}0.58 \\
(1.09)\end{array}$ & $\begin{array}{l}0.88 \\
(1.05)\end{array}$ & 0.050 \\
\hline $\begin{array}{l}\text { Years receiving } \\
\text { social grant } \\
\text { (SOCG_YRS) }\end{array}$ & $\begin{array}{l}8.40 \\
(5.57)\end{array}$ & $\begin{array}{l}9.45 \\
(7.58)\end{array}$ & $\begin{array}{l}8.90 \\
(7.18)\end{array}$ & $\begin{array}{l}0.00 \\
(0.00)\end{array}$ & $\begin{array}{l}7.67 \\
(7.17)\end{array}$ & 0.000 \\
\hline $\begin{array}{l}\text { Access to social } \\
\text { grant (SOCG) } \\
\text { (1—-social } \\
\text { grant and 0- } \\
\text { otherwise) }\end{array}$ & $\begin{array}{l}0.94 \\
(0.24)\end{array}$ & $\begin{array}{l}0.96 \\
(0.20)\end{array}$ & $\begin{array}{l}0.90 \\
(0.3)\end{array}$ & $\begin{array}{l}0.00 \\
(0.00)\end{array}$ & $\begin{array}{l}0.80 \\
(0.40)\end{array}$ & 0.000 \\
\hline $\begin{array}{l}\text { Access to credit } \\
\text { (CREDIT) (1- } \\
\text { credit and 0- } \\
\text { otherwise) }\end{array}$ & $\begin{array}{l}0.38 \\
(0.49)\end{array}$ & $\begin{array}{l}0.38 \\
(0.49)\end{array}$ & $\begin{array}{l}0.45 \\
(0.50)\end{array}$ & $\begin{array}{l}0.38 \\
(0.49)\end{array}$ & $\begin{array}{l}0.39 \\
(0.49)\end{array}$ & 0.735 \\
\hline $\begin{array}{l}\text { Membership to } \\
\text { social groups } \\
\text { (MEM_SOC) } \\
\text { (1-member } \\
\text { and 0_other- } \\
\text { wise) }\end{array}$ & $\begin{array}{l}0.58 \\
(0.50)\end{array}$ & $\begin{array}{l}0.58 \\
(0.50)\end{array}$ & $\begin{array}{l}0.53 \\
(0.50)\end{array}$ & $\begin{array}{l}0.47 \\
(0.50)\end{array}$ & $\begin{array}{l}0.55 \\
(0.50)\end{array}$ & 0.438 \\
\hline $\begin{array}{l}\text { Scheme } \\
\text { membership } \\
\text { (MEM_SCH) } \\
\text { (1-member } \\
\text { and 0-other- } \\
\text { wise) }\end{array}$ & $\begin{array}{l}0.48 \\
(0.50)\end{array}$ & $\begin{array}{l}0.42 \\
(0.50)\end{array}$ & $\begin{array}{l}0.41 \\
(0.50)\end{array}$ & $\begin{array}{l}0.44 \\
(0.50)\end{array}$ & $\begin{array}{l}0.44 \\
(0.50)\end{array}$ & 0.722 \\
\hline $\begin{array}{l}\text { Amount of } \\
\text { land (LAND) } \\
\text { (hectares) }\end{array}$ & $\begin{array}{l}1.07 \\
(1.56)\end{array}$ & $\begin{array}{l}1.35 \\
(2.62)\end{array}$ & $\begin{array}{l}2.93 \\
(4.73)\end{array}$ & $\begin{array}{l}1.28 \\
(1.85)\end{array}$ & $\begin{array}{l}1.52 \\
(2.83)\end{array}$ & 0.000 \\
\hline $\begin{array}{l}\text { Distance to the } \\
\text { nearest town } \\
\text { (MKT_DIST) } \\
\text { (minutes) }\end{array}$ & $\begin{array}{l}40.13 \\
(26.49)\end{array}$ & $\begin{array}{l}40.95 \\
(26.65)\end{array}$ & $\begin{array}{l}33.11 \\
(20.19)\end{array}$ & $\begin{array}{l}36.13 \\
(25.17)\end{array}$ & $\begin{array}{l}38.77 \\
(25.56)\end{array}$ & 0.113 \\
\hline $\begin{array}{l}\text { Log of livestock } \\
\text { value (LSTK_ } \\
\text { ASSETS) }\end{array}$ & $\begin{array}{l}3.28 \\
(1.43)\end{array}$ & $\begin{array}{l}3.29 \\
(1.45)\end{array}$ & $\begin{array}{l}3.54 \\
(1.43)\end{array}$ & $\begin{array}{l}3.42 \\
(1.48)\end{array}$ & $\begin{array}{l}3.35 \\
(1.44)\end{array}$ & 0.580 \\
\hline $\begin{array}{l}\text { Log of physical } \\
\text { asset value } \\
\text { (PHY_ASSETS) }\end{array}$ & $\begin{array}{l}3.53 \\
(0.63)\end{array}$ & $\begin{array}{l}3.55 \\
(0.62)\end{array}$ & $\begin{array}{l}3.60 \\
(0.68)\end{array}$ & $\begin{array}{l}3.55 \\
(0.69)\end{array}$ & $\begin{array}{l}3.55 \\
(0.64)\end{array}$ & 0.902 \\
\hline \multicolumn{7}{|l|}{ Farmer typologies } \\
\hline $\begin{array}{l}\text { Self-reliant } \\
\text { \& resilient } \\
\text { (FT_CLU2) }\end{array}$ & $\begin{array}{l}0.21 \\
(0.41)\end{array}$ & $\begin{array}{l}0.36 \\
(0.48)\end{array}$ & $\begin{array}{l}0.42 \\
(0.50)\end{array}$ & $\begin{array}{l}0.34 \\
(0.48)\end{array}$ & $\begin{array}{l}0.33 \\
(0.47)\end{array}$ & 0.011 \\
\hline $\begin{array}{l}\text { PsyCap and } \\
\text { future- } \\
\text { focused } \\
\text { (FT_CLU3) }\end{array}$ & $\begin{array}{l}0.29 \\
(0.46)\end{array}$ & $\begin{array}{l}0.26 \\
(0.44)\end{array}$ & $\begin{array}{l}0.23 \\
(0.42)\end{array}$ & $\begin{array}{l}0.31 \\
(0.47)\end{array}$ & $\begin{array}{l}0.27 \\
(0.44)\end{array}$ & 0.672 \\
\hline
\end{tabular}


Table 4 (continued)

\begin{tabular}{|c|c|c|c|c|c|c|}
\hline & $\begin{array}{l}Y_{\mathrm{E}}=0 \% \\
(n=113)\end{array}$ & $\begin{array}{l}0 \%<Y_{E}<50 \% \\
(n=196)\end{array}$ & $\begin{array}{l}50 \%=<Y_{\mathrm{E}}<100 \% \\
(n=71)\end{array}$ & $\begin{array}{l}Y_{\mathrm{E}}=100 \% \\
(n=68)\end{array}$ & Total & $P$ value \\
\hline $\begin{array}{l}\text { Risk-taking } \\
\text { and limited } \\
\text { interest in } \\
\text { farming } \\
\text { (FT_CLU1) }\end{array}$ & $\begin{array}{l}0.50 \\
(0.50)\end{array}$ & $\begin{array}{l}0.38 \\
(0.49)\end{array}$ & $\begin{array}{l}0.35 \\
(0.48)\end{array}$ & $\begin{array}{l}0.35 \\
(0.48)\end{array}$ & $\begin{array}{l}0.40 \\
(0.49)\end{array}$ & 0.091 \\
\hline \multicolumn{7}{|l|}{ Location (dummy) } \\
\hline $\begin{array}{l}\text { Bululwane } \\
\text { (LOC_BUL) }\end{array}$ & $\begin{array}{l}0.24 \\
(0.43)\end{array}$ & $\begin{array}{l}0.12 \\
(0.32)\end{array}$ & $\begin{array}{l}0.03 \\
(0.17)\end{array}$ & $\begin{array}{l}0.07 \\
(0.26)\end{array}$ & $\begin{array}{l}0.13 \\
(0.33)\end{array}$ & 0.000 \\
\hline $\begin{array}{l}\text { Tugela Ferry } \\
\text { (LOC_TUG) }\end{array}$ & $\begin{array}{l}0.17 \\
(0.37)\end{array}$ & $\begin{array}{l}0.19 \\
(0.40)\end{array}$ & $\begin{array}{l}0.10 \\
(0.30)\end{array}$ & $\begin{array}{l}0.09 \\
(0.29)\end{array}$ & $\begin{array}{l}0.16 \\
(0.36)\end{array}$ & 0.094 \\
\hline $\begin{array}{l}\text { Ndumo-B } \\
\text { (LOC_NDUM) }\end{array}$ & $\begin{array}{l}0.12 \\
(0.33)\end{array}$ & $\begin{array}{l}0.17 \\
(0.38)\end{array}$ & $\begin{array}{l}0.48 \\
(0.50)\end{array}$ & $\begin{array}{l}0.35 \\
(0.48)\end{array}$ & $\begin{array}{l}0.24 \\
(0.43)\end{array}$ & 0.000 \\
\hline $\begin{array}{l}\text { Makhathini } \\
\quad(\text { LOC_MAKH) }\end{array}$ & $\begin{array}{l}0.47 \\
(0.50)\end{array}$ & $\begin{array}{l}0.52 \\
(0.50)\end{array}$ & $\begin{array}{l}0.39 \\
(0.49)\end{array}$ & $\begin{array}{l}0.49 \\
(0.50)\end{array}$ & $\begin{array}{l}0.48 \\
(0.50)\end{array}$ & 0.380 \\
\hline
\end{tabular}

In brackets are standard deviations; $Y_{\mathrm{E}}$-earned income

land ownership is not that clear, households earning none of their income have the lowest average land owned. Most households classified as 'self-reliant and resilient' earn at least $50 \%$ of their income whilst it seems the majority of those categorised as 'risk-taking and limited interest in farming' earn less than $50 \%$ of the same. Whilst most households in Bululwane and Tugela Ferry have a lower percentage of earned income, the opposite is true for those in Ndumo-B. This might be linked to the scale of their operations and the performance of their farming enterprises.

\subsection{Regression results}

The regression results show several factors that affect the proportion of smallholder households' earned income (see Table 5). The assumption is that the higher the proportion of earned income, the more effort households exert to earn their living. The household head's endowment with positive PsyCap has a positive and significant effect on the proportion of earned income in a household. When farmers are classified as 'self-reliant and resilient' (FT_CLU2) and 'PsyCap \& future-focused' (FT_CLU3), the probability of earning their income increases. This demonstrates that, ceteris paribus, endowment with positive PsyCap motivates smallholders to work and earn their livelihood. Smallholders endowed with positive PsyCap are confident, optimistic and resilient, and have hope for the future. Self-reliant and resilient farmers have control over their destiny. They are not dependent on handouts from government. The findings support the trait theories which state that individuals endowed with certain characteristics will behave and respond to situations differently (Brockhaus 1982). Other studies have demonstrated the importance of PsyCap in promoting entrepreneurship in the smallholder agricultural sector (Narayanan et al. 2016; Chipfupa and Wale 2018b).

The social grant support affects the household's proportion of earned income. Both social grant-related variables, i.e., SOCG_YRS and SOCG, are negative and significant at $5 \%$ and $1 \%$ level. A $1 \%$ increase in the number of years a household has been receiving the grant decreases the proportion of earned income by 0.029 . This shows that, despite the contribution of the social grant programme to social welfare, beyond certain levels, 
Table 5 Fractional regression model results

\begin{tabular}{|c|c|c|c|c|c|}
\hline PROP_EARNED_INC & Coef. & Robust std. err. & $z$ & dy/ex & VIF \\
\hline GENDER & $0.244^{*}$ & 0.146 & 1.680 & $0.019^{*}$ & 1.24 \\
\hline EDUCAT & 0.013 & 0.016 & 0.830 & 0.012 & 1.22 \\
\hline EXPERIE & 0.007 & 0.006 & 1.300 & 0.024 & 1.34 \\
\hline DEP_RT & $-0.115^{*}$ & 0.069 & -1.670 & $-0.019^{*}$ & 1.07 \\
\hline SOCG_YRS & $-0.019^{* *}$ & 0.009 & -2.180 & $-0.029^{* *}$ & 1.35 \\
\hline SOCG & $-1.713^{* * *}$ & 0.178 & -9.620 & $-0.282^{* * *}$ & 1.39 \\
\hline CREDIT & 0.077 & 0.135 & 0.570 & 0.006 & 1.08 \\
\hline MEM_SOC & -0.105 & 0.127 & -0.830 & -0.012 & 1.09 \\
\hline MEM_SCH & $0.431^{* * *}$ & 0.143 & 3.010 & $0.040^{* * *}$ & 1.29 \\
\hline LAND & $0.044^{* *}$ & 0.017 & 2.550 & $0.016^{* *}$ & 1.22 \\
\hline MKT_DIST & -0.002 & 0.002 & -0.960 & -0.018 & 1.11 \\
\hline LSTK_ASSETS & 0.045 & 0.042 & 1.060 & 0.032 & 1.12 \\
\hline PHY_ASSETS & -0.135 & 0.099 & -1.350 & -0.101 & 1.16 \\
\hline FT_CLU2 & $0.492^{* * *}$ & 0.147 & 3.340 & $0.038^{* * *}$ & 1.32 \\
\hline FT_CLU3 & $0.288^{*}$ & 0.168 & 1.720 & $0.017^{*}$ & 1.45 \\
\hline LOC_BUL & $-0.616^{* *}$ & 0.259 & -2.380 & $-0.013^{* * *}$ & 1.33 \\
\hline LOC_TUG & -0.090 & 0.206 & -0.440 & -0.003 & 1.42 \\
\hline LOC_NDUM & $0.650^{* * *}$ & 0.170 & 3.810 & $0.040^{* * *}$ & 1.42 \\
\hline _cons & 0.273 & 0.425 & 0.640 & & \\
\hline Number of obs & 446 & & & Mean VIF & 1.26 \\
\hline Log pseudolikelihood & -184.8 & & & & \\
\hline Pseudo R2 & 0.45 & & & & \\
\hline
\end{tabular}

the support tends to diminish smallholders' motivation to earn their living. The more years they receive social grants, the higher the external locus of control. The larger the contribution of unearned income, the lower the internal locus of control. There is evidence that shows that social transfers may lead to a reduction in the supply of casual agriculture labour as they make work less attractive (Moffitt 2002). If this is not off-set by on-farm employment, it will result in the reduction in household earnings and an unsustainable dependency on the grant support as a source of livelihoods. The findings confirm other studies showing that social grants act as a disincentive for smallholders to engage in market-oriented farming (Bertrand et al. 2003; Sinyolo et al. 2017). However, they are contrary to conclusions made by other studies (Ardington et al. 2009; Daidone et al. 2019). Daidone et al. (2019) concluded that social transfers do not result in reduction in smallholder work effort whilst Ardington et al. (2009) showed that social transfers increase the employment of prime-age adults. The differences in findings could be due to the different contexts, and indeed, Daidone et al. (2019) found results to differ according to the local context in the country studied.

Membership to an irrigation scheme (MEM_SCH) has a positive and significant effect $(P<0.001)$ on the proportion of earned income in a household. The resources (knowledge and skills, water, financial and material support) available to smallholders through the schemes enhance their propensity to put more effort and be productive. Moreover, the competitive environment inside the irrigation scheme motivates farmers to work 
and perform better than their counterparts. These findings are in line with other studies. Dube (2016) showed that smallholders in irrigation schemes perform better in terms of productivity compared to those outside of the scheme. After accounting for all other factors, Hagos et al. (2009) showed that the income earned under smallholder irrigation systems is higher (US\$323/ha) compared to that for rain-fed farming systems (US\$147). This demonstrates the importance of small-scale irrigation systems in improving the incomes of rural households.

The amount of land owned (LAND) by a smallholder household is also positive and significant $(P<0.05)$ in affecting the proportion of income earned by the household. A $1 \%$ increase in the land available to smallholder farmers results in a 0.016 increase in the proportion of earned income. Due to the water scarcity challenges, availability of irrigable land can be an incentive to engage in farming and will enhance the farmers' chances of earning more income. The challenge, though, is the scarcity of irrigable land. Only 5.5\% of the total cultivable land in Africa is irrigable (Abrams 2018). Thus, smallholders in the schemes have a marginal latitude for expanding land under cultivation. Even for those irrigating outside the schemes, increasing land under cultivation is affected by the limited available water resources. The study results also showed that the gender of the household head (GENDER) positively and significantly affects the proportion of earned income. Due to cultural and social norms, men have more opportunities for off-farm work engagement (e.g., casual and permanent employment) compared to women (Holmes and Jones 2011). This means women are most likely to be less involved in off-farm employment activities compared to men (Mendola and Carletto 2012), which reduces their opportunities for earning more income. Moreover, the reproductive roles of women, due to gender stereotyping and other cultural traditions, act as demotivating factors or constraints to their participation in economic activities (Holmes and Jones 2011; Kidder et al. 2014). Matshe and Young (2004) also found similar results from a study in rural Zimbabwe.

The dependency ratio (DEP_RT) negatively and significantly affects the proportion of earned income. A $1 \%$ change in the dependency ratio decreases the proportion of earned income by 0.019 . This result is contrary to expectations. It was expected that a higher economic burden to the household (dependency ratio) would motivate households to search for more opportunities to earn income in order to enhance their ability to provide for their families. However, there could be two explanations for this finding. The number of dependents (less than 15 and more than 60 years) in a rural household could be linked to the income received from social grant support. The more the dependents, the greater the chance that some of them receive social grant support. As discussed above, such unearned income sometimes acts as a disincentive to work. Second, more dependents restrict the mobility of the few productive members of a household. This also reduces their opportunities for earning income.

Spatial differences also affect smallholder farmers' level of earned income. The probability of smallholders from Bululwane earning an income compared to those in Makhathini is low whilst that of farmers from Ndumo-B is high. The spatial effects could be related to differences in the level of development of the irrigation schemes, collective management and institutional arrangements, amongst others (Muchara et al. 2014; Wale and Chipfupa 2018). Bululwane irrigation scheme is one of the poorest districts in 
South Africa. Agricultural production in the scheme is only limited to areas where there is adequate water pressure for sprinkler irrigation (1 ha plot per farmer). Scheme management has also been a challenge because of conflicts that affect motivation and collective action processes critical to the production and marketing of produce (Muchara et al. 2014). Contrary to Bululwane, smallholders from Ndumo-B seem to be more organised. They have minimum water challenges. Their irrigation plots are bigger with an average of 10 ha per farmer. The scheme has been supported by agencies such as TechnoServe who contract farmers to produce crops and guarantee the market. In terms of equipment, Ndumo-Irrigation scheme has newer and more sophisticated farming equipment compared to Bululwane, which makes them more efficient in production.

\section{Conclusions and policy implications}

Understanding the motivation that smallholders have for working and earning their livelihoods is critical in making agricultural policies work for the rural poor. The study demonstrates that weak investment in the human and social capital development impacts negatively on smallholders' PsyCap endowment, internal locus of control and hence their drive in exerting more effort, investing on the farm, and earning their livelihoods. Consequently, poverty of endowment in PsyCap will translate to minimal impact of rural development policies on the welfare of smallholder farming households. It is the opportune time for agricultural research and policy to recognise the value of PsyCap as a critical livelihood asset. Resources should be committed to improving this asset amongst smallholders. Valuable lessons can be learnt from the corporate sector, which has since invested in the asset to improve the performance of workers in the workplace.

The study challenges the blanket notion that social transfers, such as social grants, are good or bad for smallholder agriculture. Context is important when assessing the impacts of such programmes as their unintended effects can be detrimental. Our conclusion, although somewhat controversial given the motivation for such programmes, is that, at present social grants is inclined to making work less attractive in the rural communities in South Africa. Although some studies have shown that cash transfers reduce credit constraints and increase agricultural investment, for some communities, this effect is not large enough to nullify the negative impact on the motivation to work. Whilst recognising the value of the social grant programme in reducing poverty, there is a need to find mechanisms of improving its desirable impacts.

Water scarcity is a significant challenge in smallholder farming, and irrigation is meant to address that challenge. Hence, promoting small-scale irrigation will enable smallholders to work and earn their livelihoods. There is a need to increase capacity utilisation of existing schemes, implement irrigation expansion plans, and identify areas for establishing new schemes. The findings also show that cultural and social norms continue to place women in a position where they are unable to engage in both off-farm and on-farm economic activities. This affects the propensity of women-headed households to work and earn income. Thus, there is a need to continue promoting strategies for women economic empowerment, including their agency. Investment and improvement in existing infrastructure (such as roads, electricity, childcare facilities and health centres) will increase women's employment opportunities outside of their homes. 
Future studies can further this research through an intertemporal study meant to quantify both the negative and positive impacts of social transfers on agricultural investment, land utilisation, smallholder labour productivity and market participation.

\section{Supplementary information}

Supplementary information accompanies this paper at https://doi.org/10.1186/s40008-020-00199-0.

Additional file 1. PCA results and K-Means clustering ANOVA tables.

\section{Acknowledgements}

The authors would like to thank the Water Research Commission for funding this study which was undertaken as part of a project titled 'Water use productivity associated with appropriate entrepreneurial development paths in the transition from homestead food gardening to smallholder irrigation crop farming in KwaZulu-Natal Province'. The project final report is available at http://www.wrc.org.za.as 'WRC Report No. 2278/1/18'. Special mention goes to the enumerators who worked hard during the data collection.

\section{Authors' contributions}

Both authors contributed to the design of the study, data collection, data analysis and development of the manuscript. Both authors read and approved the final manuscript.

\section{Funding details}

This work was supported by the Water Research Commission of South Africa under Grant [K5/2278/4], 2014-2017.

\section{Availability of data and materials}

Data are available upon request from the main author.

\section{Competing interests}

There are no potential competing interests in relation to the work presented in this paper.

Received: 24 October 2019 Revised: 22 January 2020 Accepted: 19 February 2020

Published online: 05 March 2020

\section{References}

Abrams L (2018) Unlocking the potential of enhanced rainfed agriculture. Report No. 39. Stockholm International Water Institute: Stockholm

AGRA (2017). Africa agriculture status report: the business of smallholder agriculture in Sub-Saharan Africa (Issue 5), Alliance for a Green Revolution in Africa (AGRA): Nairobi, Kenya

Aliber M, Hart TBG (2009) Should subsistence agriculture be supported as a strategy to address rural food insecurity? Agrekon 48(4):434-458

Ardington C, Case A, Hosegood V (2009) Labor supply responses to large social transfers: longitudinal evidence from South Africa. Am Econ J 1(1):22-48

Bembridge TJ (2000) Guidelines for rehabilitation of small-scale farmer irrigation schemes in South Africa. Pretoria, Water Research Commission

Bertrand M, Mullainathan S, Miller D (2003) Public policy and extended families: evidence from pensions in South Africa. World Bank Econ Rev 17(1):27-50

Bigodeza JC, Berentsen PBM, De Graaff J, Lansink O (2009) A typology of farm households for the Umutara Province in Rwanda. Food Security, Vol. 1, pp 321-335

Brockhaus RH (1982) The psychology of the entrepreneur, Encyclopedia of Entrepreneurship, pp 39-57

Chakona G, Shackleton CM (2019). Food insecurity in South Africa: To what extent can social grants and consumption of wild foods eradicate hunger?, World Development Perspectives, Vol. 13, pp 87-94

Chipfupa U (2018) Entrepreneurial development pathways for smallholder irrigation farming in KwaZuu-Natall: typologies, aspirations and preferences, PhD, University of KwaZulu-Natal

Chipfupa U, Wale E (2018a) Explaining smallholder aspirations to expand irrigation crop production in Makhathini and Ndumo-B, KwaZulu-Natal, South Africa. Agrekon 57(3-4):284-299

Chipfupa U, Wale E (2018b) Farmer typology formulation accounting for psychological capital: implications for on-farm entrepreneurial development. Dev Pract 28(5):600-614

Daidone S, Davis B, Handa S, Winters P (2019) The household and individual-level productive impacts of cash transfer programs in Sub-Saharan Africa. Am J Agric Econ 101(5):1401-1431

Danso G, Drechsel P, Wiafe-Antwi T, Gyiele L (2002) Income of farming systems around Kumasi. Urban Agriculture Magazine 7:5-6

Davidson R, MacKinnon JG (1981) Several tests for model specification in the presence of alternative hypotheses. Econometrica 21:781-793

De Satge R (2002) Learning about livelihoods: insights from Southern Africa. Oxfam, Johannesburg

DFID (1999) DFID sustainable livelihoods guidance sheets. Department for International Development, London

Dube K (2016) Implications of rural irrigation schemes on household economy a case of Lower Gweru Irrigation Scheme, Zimbabwe. S Afr J Agric Ext 44:75-90 
Fanadzo M (2012) Revitalisation of smallholder irrigation schemes for poverty alleviation and household food security in South Africa: a review. Afr J Agric Res 7(13):1956-1969

Frese M, Gielnik MM (2014) The psychology of entrepreneurship. Ann Rev Organ Psychol Organ Behav 1(1):413-438

Gagné M, Deci EL (2005) Self-determination theory and work motivation. J Organ Behav 26(4):331-362

Godfrey EB, Gordon ND, Knight LC, Aber JL, Allen L, Richter L, Group SR (2016) Which eligible households get grants? demographic correlates of receipt in South Africa. Dev South Afr 33(6):774-789

Goswami R, Chatterjee S, Prasad B (2014) Farm types and their economic characterization in complex agro-ecosystems for informed extension intervention: study from coastal West Bengal, India. Agric Food Econ 2(5):1-24

Hagos F, Makombe G, Namara RE, Awulachew SB (2009) Importance of irrigated agriculture to the Ethiopian economy: capturing the direct net benefits of irrigation. IWMI, Colombo

Hanass-Hancock J, McKenzie TC (2017) People with disabilities and income-related social protection measures in South Africa: Where is the gap? Afr J Disabil 6:1-11

Heckhausen J, Heckhausen H (1991) Motivation and action. Cambridge Press, New York

Heckhausen H, Rheinberg F (1980) Lernmotivation im Unterricht, erneut betrachtet [a new look at motivation to learn in the classroom]. Unterrichtswissenschaft 8(1):7-47

Holmes R, Jones N (2011) Gender inequality, risk and vulnerability in the rural economy: refocusing the public works agenda to take account of economic and social risks. Overseas Development Institute, London

Jayne TS, Yeboah K, Henry C (2017) The future of work in African agriculture trends and drivers of change. Working Paper No. 25. In: International Labour Organization

Kidder T, Mapandi Z, Ortega H (2014) Not'women's burden': how washing clothes and grinding corn became issues of social justice and development. Gender Dev 22(3):495-513

Lawler EE III, Porter LW (1967) Antecedent attitudes of effective managerial performance. Organ Behav Hum Perform 2(2):122-142

Luthans F, Luthans KW, Luthans BC (2004) Positive psychological capital: beyond human and social capital. Bus Horiz 47(1):45-50

Matshe I, Young T (2004) Off-farm labour allocation decisions in small-scale rural households in Zimbabwe. Agric Econ 30(3):175-186

McClelland DC, Winter DG (1969) Motivating economic achievement. Free Press, New York

Mendola M, Carletto C (2012) Migration and gender differences in the home labour market: evidence from Albania. Lab Econ 19(6):870-880

Moffitt RA (2002) Welfare programs in labour supply. In: Auerbach AJ, Feldstein M (eds) Handbook of public economics, vol 4. Elsevier, Amsterdam, pp 2390-2430

Muchara B, Wale E, Ortmann GF, Mudhara M (2014) Collective action and participation in irrigation water management: a case study of Mooi River irrigation scheme in KwaZulu-Natal Province, South Africa. Water SA 40(4):699-708

Nampanya S, Suon S, Rast L, Windsor P (2012) Improvement in smallholder farmer knowledge of cattle production, health and biosecurity in southern Cambodia between 2008 and 2010. Transbound Emerg Dis 59(2):117-127

Narayanan G, Singh P, Chahal VP (2016) Factors influencing agri-preneurial success among rural women entrepreneurs: an empirical analysis. Indian J Agric Sci 86(9):1214-1219

Papke LE, Wooldridge JM (1996) Econometric methods for fractional response variables with an application to 401 (k) plan participation rates. J Appl Econ 11(6):619-632

Phakathi S, Wale E (2018) Explaining variation in the economic value of irrigation water using psychological capital: a case study from Ndumo B and Makhathini, KwaZulu-Natal, South Africa. Water SA 44(4):664-673

Ramalho EA, Ramalho JJ, Murteira JM (2011) Alternative estimating and testing empirical strategies for fractional regression models. J Econ Surv 25(1):19-68

Rheinberg F (1989) Zweck und Tatigkeit [Purpose and activity]. Hogrefe, Gottingen

Rheinberg F (2004) Motivationsdiagnostik [measurement of motivation]. Hogrefe Verlag, Germany

Shiferaw B, Tesfaye K, Kassie M, Abate T, Prasanna BM, Menkir A (2014) Managing vulnerability to drought and enhancing livelihood resilience in sub-Saharan Africa: Technological, institutional and policy options. Weather Clim Extr. 3:67-79

Sigelman L, Zeng L (2000) Analyzing censored and sample-selected data with Tobit and Heckit Models. Polit Anal 8(2):167-182

Sinyolo S, Mudhara M, Wale E (2017) The impact of social grant-dependency on agricultural entrepreneurship among rural households in KwaZulu-Natal, South Africa. J Dev Areas 51(3):63-76

Statistics South Africa (2016) Community Survey 2016. Report No. P0301. Statistics South Africa: Pretoria

Statistics South Africa (2017) Living conditions of households in South Africa: an analysis of household expenditure and income data using the LCS 2014/2015: Pretoria

Statistics South Africa (2018) General household survey 2017. Statistics South Africa, Pretoria

Statistics South Africa (2019) General household survey 2018. Statistical Release P0318. Statistics South Africa, Pretoria

Treasury National (2019) Budget review 2019. National Treasury, Pretoria

Twomlow S, Mugabe FT, Mwale M, Delve R, Nanja D, Carberry P, Howden M (2008) Building adaptive capacity to cope with increasing vulnerability due to climatic change in Africa-a new approach. Phys Chem Earth Parts A/B/C 33(8):780-787

Vroom VH (1964) Work and motivation. Wiley, New York

Wale E, Chipfupa U (2018) Appropriate entrepreneurial development paths for homestead food gardening and smallholder irrigation crop farming in KwaZulu-Natal Province. WRC Report No. 2278/1/18", Water Research Commission of South Africa, Pretoria

Wooldridge JM (2010) Econometric analysis of cross section and panel data, 2nd edn. The MIT Press, Cambridge

\section{Publisher's Note}

Springer Nature remains neutral with regard to jurisdictional claims in published maps and institutional affiliations. 